\title{
Islam in Life of the Polish-Lithuanian Tatars (The XIV-XIX Centuries)
}

\author{
Yakov Y. Grishin ${ }^{1}$ \\ ${ }^{1}$ Kazan (Volga Region) Federal University, Kazan, Russia \\ Correspondence: Yakov Y. Grishin, Kazan (Volga Region) Federal University, Kremlyovskaya Street 18, Kazan \\ 420008, Russia. E-mail: grishin.42@mail.ru
}

Received: April 14, 2015 Accepted: April 20, 2015 Online Published: April 27, 2015

doi:10.5539/jsd.v8n4p119 URL: http://dx.doi.org/10.5539/jsd.v8n4p119

\begin{abstract}
The urgency of the problem under investigation is caused by its being poorly studied in the national historiography. It is devoted to one of the main features distinguishing the Polish-Lithuanian Tatars from others religion which they kept from the moment of emergence in the Grand Duchy Lithuania, further the Polish-Lithuanian Commonwealth. It was the sphere which is most attracting attention. Particular attention is paid to the peculiarities and specific character of the religious life of the Polish-Lithuanian Tatars, the disclosure of the activities of religious gmina - dzhemat that emerged in the XIV-XV centuries, mosques, construction of which began almost since "osadnichestvo" of Tatars, the place and role of the mullahs as authoritative, educated people and who had a great impact on the daily lives of their parishioners, the description of existing peculiar rituals associated primarily with the three most important moments of life: birth, marriage and death, Tatar cemeteries usually located at the mosques or at high hillocks, waqfs, and so on. This article is based on the basic principles of historical knowledge: the historicism and objectivity, allowing to provide scientific approach to the analysis of the historical processes happening in life of the Polish-Lithuanian Tatars. Materials of the article can be of interest to students, masters, graduate students, teachers specializing on Islam history, for those who are engaged in its studying in Eastern Europe.
\end{abstract}

Keywords: dzhemat, muezzin, zirech, khutbah, mihrab, proselytizm, imam

\section{Introduction}

It is known that Tatars as osadniks appear in the Grand Lithuanian Duchy in the XIII-XIV centuries (Borawski, 1986) thanks to activity of its princes and first of all Witold (1392-1430) (Kirkor, 1854).

It was he who founded Tatar osadnichestvo in their country (Źdan, 1929).

When settling Tatars in the principality, Witold acknowledged their complete freedom of religion and customs.

Such conditions of osadnichestvo were extremely favorable, and so there is nothing surprising in the fact that voluntary influx of large groups of Tatars to lands of the principality began. Especially strong flow of emigrants was observed in 1409. Significant number of them settled in the Grand Duchy of Lithuania.

Muslims felt gratitude to the Grand duke for his care.

Witold's death didn't interrupt emigration of Tatars to the Lithuanian lands, however representatives of the Crimea start prevailing more and more among them. It happened because the Crimean khanate allocated from the Golden Horde became the arena of big disorders.

The process of the settlement of Tatars in borders of the Polish-Lithuanian state proceeded also in the XVI century, but it wasn't so massive any more.

Thanks to Witold's ability, Lithuanian, (and further the Polish-Lithuanian) Tatars became the integral part in life of Poland and Lithuania throughout more than 6 centuries (Grishin, 1997; Khayrutdinov, 2014).

They tied their fate with the Commonwealth and remained faithful to it, including difficult periods in its history (XVII-XVIII centuries).

The Polish-Lithuanian Tatars as Muslims treated the Sunni direction (Kryczyǹski, 1938) practiced by most of believers of Islam in the world. 
As rather considerable group, keeping contacts with sworn brothers from the Crimea and the Volga region, it organized the religious life on constant legal bases and customs. It is safe to say that through many centuries the Lithuanian-Polish Tatars kept the cultural and ethnic difference, mainly thanks to cultivation of Islam. The religious factor united them in the gmina, allowed to keep distinctive ceremonies, allowed to get married in own circle of believers.

Remote from the Muslim centers, they nevertheless remained faithful to the religion, including in it the certain elements originating in ancient times. Long cohabitation to Christians had a certain impact on the Tatar ceremonialism. Nevertheless, the Polish Tatars didn't depart from the main principles of Islam sitting deeply in consciousness of each of them.

\section{Methodological Framework}

The author of article was guided, first of all, by the principles of historicism and scientific objectivity. The principle of historicism is a review of historical events and phenomena in the chronological development and in communication with each other.

It allows to study the process of appearance of Tatars in the Grand Lithuanian Duchy, further the Polish-Lithuanian Commonwealth, their osadnichestvo, religious life throughout XIV - XIX centuries.

The author also used the historical-comparative method, based on a comparison of the historical development of the various events. This method was used to study religious aspects of the Polish-Lithuanian Tatars.

From special historical methods, synchronous (studying of the events occurring at the same time) and diachronic (studying and comparison of the typical events occurring at different times) are used in research. The synchronous method allows to understand influence of a historical context on character and dynamics of events, and also interrelations between them. The diachronic method promotes the analysis of features of various processes.

The system analysis is also used in the present article to examine the object of study as part of an overall system of relations in the XIV - XIX centuries.

\section{Results}

The group of settled Tatars, or some Tatar villages created religious gmina - dzhemat. Its competence included election of ecclesiastics and the solution of the questions concerning a gmina. In particular, management of waqf property. If required, meetings were organized, and captains, or the Tatar cornets directed them. The latter had considerable influence on the course of meetings, especially when electing imams.

Gmina began to form in the XVI century, and possibly earlier. Anyway, in the XVII century in the Grand Duchy of Lithuania there were 40 of them, at the end of the XIX century - beginning of XX century - 20 (Akti o litovskih tatarah, 1906).

Muslim gmina in Poland and Lithuania as Chazbiewicz writes (1994), were independent from each other and besides their small number and remoteness often differed in some features of forms of a prayer or customs. It was a consequence of various stages of the Tatar osadnichestvo, origin of the arriving osadniks, etc. Muslims in Poland and Lithuania had no any integrated organization on those lands during the entire period of the history practically till the intermilitary period. Almost each gmina was aloof and donated alms in its own way.

The mosque was the symbol of a gmina, although it should be remembered that not all dzhemats could have them.

The mosques built among the Polish-Lithuanian buildings were modest, low. They stood out, therefore, not with architecture, but religious exotic for this part of Europe. They were supported by a religious gmina or a rich layer of Tatar misters. During the first period of osadnichestvo there was no need to get permissions to construction of mosques. However then the problem began to be regulated on the principles similar to Orthodoxy, that is, it was necessary to get the highest permission for construction of the temple.

The first mosques were built approximately in the XIV-XV centuries in places of a big congestion of Tatars. At the end of the XIX - early XX century in the Northwest region of Russia there were about 20 mosques (Akti o litovskih tatarah, 1906).

Muslim sanctuaries generally were built by local carpenters. Therefore they were a typical sample of wooden architecture. Some of them reminded rural churches or orthodox churches. The mosques built by Jewish masters had many similar features with the synagogues surrounding them. There was no Byzantine or Armenian influence on the architecture of mosques. 
The internal furniture of the Polish-Lithuanian mosques also was quite modest. Most of them consisted of two parts - man's and female. The certain room for women, so-called babinets, could be found only in the Polish-Lithuanian sanctuaries. In mosques of other Muslim people such internal division isn't present. The first information about this unique phenomenon, we again find in the "Traktat o polskih tatarah." His author reports that "In the middle of the XVI century in some local mosques there were special rooms for women where men had no right to enter as it would lead to violation of the rules, forbidding praying together with brides". A female half usually settled down in the left side of a mosque. It was much less than male. It was separated by a thin wooden wall with a very narrow window. It was closed by a white transparent curtain. Each had a special entrance. The walls inside the mosque were mostly non-white (Akti o litovskih tatarah, 1906).

Prayers were said in a male half. There usually was mihrab in front of the prayer hall or carol in the wall. It showed the direction to Mecca and had a semicircular or polygonal form. Sometimes mihrab was decorated with a beautiful ornament. The mullah got up facing Mecca during the general prayer in a mosque. To the right of a mikhrab there was a so-called minbar (a small eminence with a ladder). In the Polish-Lithuanian mosques it was done most often of wood. Small roofs were built over some of them, or they were covered with a canopy. During a prayer the mullah read hutba from a minbar (prayer). Monarchical orders were led up to believers, and appeals to fight against tsarism were proclaimed during an era of sections of Poland. In many mosques, opposite to a mikhrab there was a small gallery on the top of the wall, separating female part from male. The muezzin said azan on it during a prayer. Decoration of mosques with the Tatar regimental banners is also one of the most interesting and forgotten customs (Konopacki, 1973).

According to Islam precepts, when starting a prayer one should have to make ritual ablution of a body. To do this, in the vestibule there were two special rooms and one could use vessels for ablution there (Akti o litovskih tatarah, 1906).

In general daily ablution was an essential element of life of Muslims of the Polish-Lithuanian Commonwealth. According to the available data, since the beginning of the last century in winter Muslims washed in bathtubs, and in summer - in the rivers. Perhaps, in the XVIII and XIX centuries because of higher level of hygiene of Tatars, mortality among them was lower, than among Christians.

When entering a mosque, people left footwear before a threshold. During a prayer Muslims had to be with the covered heads, sitting on the pieces of cloth outspread on a floor. The requirement of the Koran about donating alms among the Polish-Lithuanian Tatars lost its initial meaning. It became usual distribution between participants of a prayer of the alms (sadaka) consisting of rolls, or sweets which received the blessing beforehand.

During a month of a Ramadan all Muslims had to refrain from food, drink, smoking of tobacco, sexual relations from sunrise to sunset. However the Polish-Lithuanian Tatars seldom followed these rules. During Ramadan in mosques were evening prayers - taraweeh.

The main duty of every Muslim was pilgrimage to the shrine of Islam - Mecca and Medina. But its realization depended first of all on money. Only few Tatars of the Polish-Lithuanian Commonwealth were able to afford to make such trip. The oldest mention of such pilgrimage refers to 1558 .

The special role in the religious gmina was played by the mullah (imam). It should be noted that the latter term was rarely used in Lithuania. In sources the mullah more often called a "molna", is more rare - the Tatar priest. He was, as a rule, elected by parishioners at general meeting of a gmina. In case of violation of moral standards by the imam, he could be defrocked, also through a gmina - dzhemat. In the second half of the XVIII century, for example, in the village of Gribovoi "the mullah, having the wife, had sexual relations with the Christian", the Christian was cut, and the mullah was defrocked" (Zakrzewski, 1989). Dzhemat could also elect the assistant to the mullah "the vice-mullah", we meet a mention of it in 1818. According to indirect data, such practice was not uncommon. Perhaps, "the vice-mullah" should be identified with the muezzin", - A. Zakzhevsky considers (Zakrzewski, 1989).

The imam, as a rule, was the authoritative person. He had influence, sometimes very strong, on his "personnel". The knowledge of fundamentals of religion, and till the XVIII century - knowledge of the Arabic language was the main requirement for the candidate for a position of the ecclesiastic. If to trust a report of 1558, in the XVI century ecclesiastics sometimes were invited from the Muslim countries (Muchlinsski, 1858). In the XVII century more educated mullahs arrived from the Crimea. Their signatures in Arabic script are found on a number of documents (Akti o litovskih tatarah, 1906).

Besides, there was an attempt to train priests from the surrounding by sending young Tatars to study to oriental 
countries. The papal legate Possevino Antoni, in particular, informed on it from Vilno in 1579 (Tyszkiewicz, 1989).

However it should be noted that the considerable part of priests had training at home according to the decision of the Warsaw and Lublin diets (respectively 1556/1557 and 1569) when Islamic schools were open. Muslim pastors successfully taught Religious Sciences, as well as reading and writing Arabic alphabet until the middle of the XVII century. Later there came times of military destructions, resettlements, influx of new believers from Volga and the Black Sea steppes, so ability to write in the Arab alphabet became a rarity. Studying of Islam together with limited training in the Arabic language is partially restored only in the second half of the XVIII century (Bohdanowicz, 1997).

In the XVIII and XIX centuries as Leon and Stanislav Krychinskiye established, old, vigorous, educated, dignified officers became mullahs (for example, in Slonim, Mizhe, Novogrudka), making elite of the Tatar community (Kryczyǹski, 1938).

In the XIX century there were absolutely other conditions, also in imperial Russia. Loyalty and the mass flow of the Tatars in the military service led to their russification. Introduction of obligatory use of Russian in mosques and cemeteries led to disappearance of gravestones with the Arab and Polish inscriptions (Bohdanowicz, 1997).

Execution of religious ceremonies (Borawski, Dubiǹski 1986) was one of fundamental obligations of the mullah. "And the mullah is necessary to us when someone is born or will die", - Tatars explained their need to have the priest.

Ceremonies of the Polish-Lithuanian Tatars first of all were connected with three major moments of life: birth, marriage and death. Though they were all of Muslim character, however it was possible to notice also certain elements of paganism, and also some features of Christianity (Zakrzewski, 1989; Woronowicz, 1937).

Mosques were remarkable elements in the places of residence of the Polish-Lithuanian Tatars. Besides, there were Tatar cemeteries. Two terms of the Arab origin were used referring to cemeteries. The first, the oldest and widespread - зиречь (зират), the second term - мизар (мазар). It was used by mainly Tatar population in Podlyasye.

Graves in cemeteries were located in neat rows. Till the XVII century stone gravestones of the Polish-Lithuanian Tatars had no drawings and inscriptions. The first of them, probably, appeared only approximately in the middle of the XVII century under the influence of Poles. The inscriptions made by local bricklayers are very laconic, but also they have many spelling errors. Usually the Arab, Polish, or Belarusian texts were written, but only the Arabic script was used. Most of all fragments from the Koran were used. Sometimes Turkish texts could also be written.

Researchers of the Tatar folklore established that texts in the Turkish language were located on gravestones of the Muslims, who had grounds of the average sizes. There were no of them on graves of rich Tatars. Inscriptions were always located on big stones at the head of the dead, but occasionally at the feet.

Cemeteries, as S. Krychinsky wrote during the intermilitary period (Kryczyǹski, 1938), were picturesque and melancholic. They were settled down, as a rule, at mosques or on high hillocks. In spring and in summer trees, bushes and herbs violently turn green, covering the stone steles which are sticking out of the earth with the Arab inscriptions.

The territory of a cemetery with a mosque was usually dug round and surrounded with a fence and stone, low walls.

In summer sunny weather mizars from the surrounding fields of ripening grain looked extremely picturesque, nothing resembled a gaping void of cemeteries of Oriental countries (Kryczyǹski, 1938).

Mullahs, except ceremonies, executed also other functions, in particular, the notary, certifying wills of the tribes people, which in the form didn't differ practically from the Christian (Akti o litovskih tatarah, 1906).

Mullahs at the same time certified also mortgage letters, stored documents. From the middle of the XVI century they were obliged to run civil cases, and also registers of births of the religious gmina. In particular, they were responsible for issue of birth certificates. It was important at identification of a noble origin in the XIX century.

But not all the mosques had record keeping (Kołodziejczyk, 1986).

According to the Constitution of 1670, mullahs helped to conduct census of the Tatar population paying a tax. It, however, caused a protest among some Tatars of Trotsky voivodeship, who complained that mullahs didn't include rich Tatars in registration tax lists, while the poor became merchants and handicraftsmen" (Zakrzewski, 
1989).

Mullahs also regularly took the oath of their co-religionists in court.

The rite was usually held in a mosque. If there was not any mosque in the area, the presence of mullahs was enough. The beginning of the typical Tatar oath sounded like this: "I, Moustapha Senkevich, swear to the Lord Supreme which created the sky and the earth, and transferred to us through Al-Koran ..." (Zakrzewski, 1989).

In the XVIII century mullahs were appointed to the positions of chaplains in regiments of forward guards of the Lithuanian army (Tyszkiewicz, 1989).

The Polish-Lithuanian Tatars also had religious courts (Zakrzewski, 1989).

According to the law, the mullah had the right of execution of some purely judicial functions, so, for example, cases connected with disobedience of children to parents, settlement of disputes about a private property, arising between Mohammedans according to wills or at the division of hereditary property, etc.

Their acquaintance (in various degree) with the Muslim right - Shariat, was argument in favor of a judicial role of mullahs, obviously. Consideration of various questions in mosques was usual practice. At the beginning of the XIX century Tadeush Chatsky noted the low level of legal education in the clergy. Nevertheless mullahs continued to perform judicial functions even in the XX century.

It should be noted that actually parishioners seldom addressed to mullahs, preferring to have legal proceedings in legal agencies (Akti o litovskih tatarah, 1906).

Mullahs, being the only experts in questions of religion and culture of Islam, taught also at theological schools. The author of a report of 1558 wrote about a mullakh: "they also teach our children" (Muchlinski, 1858). In 1570 the Czech Jesuit Balthasar Hostoumski informs the father: "In the city of Vilno many nationalities as well Tatars, have the sanctuary and school where they learn Arabic" (Piechnik, 1973). Really, children of Tatars got acquainted with fundamentals of religion, and also learned to read and write in Arabic at schools. Preservation of such situation in the second half of the XVII century was provided with links to Islamic culture of considerable part of Tatars. This is evidenced by the inscriptions in Arabic script on the documents, which were about $25 \%$ during that period, the others were in Latin. It seems that the study of the Arabic language was more practiced in the XVI century. In the next centuries Tatars began to lose their native language, and mullahs for religious items used books of own production which were formed in the Arabic script (Zakrzewski, 1989).

During reduction of the Tatar population mullahs had to serve also the parishioners who lived scattered. Mullah of the old Tatar center could also serve young Tatar colonies. For example, the found Tyszkiewicz, 1989 note testifies about it. It is a note on subordination of the radzivillovski Tatar sieges in Osmolov and the Horde (near Kletsk) to the mullah from Novogrudk in 1575. (Tyszkiewicz, 1989).

In the middle of the XIX century, according to Mukhlinsky, there were only 12 mullahs in the Western provinces of Russia (Mukhlinsky, 1887).

As we have seen, the Muslim congregations were given land (waqfs), and they were given money. Mulla in general had his farm, as he had also own arable lands and orchards.

However, during the inventory there was not the division of land on waqf and belonging to Mullah. Mullahs, being land owners, were obliged to bear a comission.

The allotments belonging to a Muslim religious community were rather small. Therefore various gifts of believers were a source of the constant income of mosques. In 1802, for example, the Tatars from Lostaya donated two "zlotys" to Dovbuchistskoy mosque. Monetary wills were the essential share of financing (Kryczyǹski, 1930).

On the whole, domestic life of Mullah is not different from the rest of his parishioners, at home, in the field, in the garden, he wears the same clothes as everyone else. At execution of occasional service, and in the cities and usually, the mullah puts on the wide cassock similar to the cut of the robe of the orthodox priest, and velvet hat, with white laces, in a form reminding kamilavka" (Akti o litovskih tatarah, 1906).

Until the conflict and emigration, some noble Tatar families in Turkey at the end of the XVI century tried to create the Lithuanian Muslim religious organization, separate of the Crimea and Istanbul. But they could not do it (Kryczyǹski, 1938; Tyszkiewicz, 1989). Dependence still remained. The second attempt of creation of separate Spiritual Directorate with its own muftiate in Lithuania made in 1842 was not also successful. However, in this case, it was talked of it in a different situation, when there was Polish Kingdom. It goes without saying, the Russian State wanted to have complete control over Muslims on the former Polish lands. Therefore in the 
Western provinces they submitted to Muslim spiritual directorate - the muftiate in the Crimea. However, as Ya. Tyshkevich (1989) notes, this management, fortunately, had formal character. It didn't interfere with their affairs absolutely. Believers continued to elect Imams in the gmina (Bohdanowicz, 1997), who were approved by "local Provincial board and Taurian Mohammedan spiritual board to which all Lithuanian Tatars were subordinated in affairs of belief" (Akti o litovskih tatarah, 1906). Thanks to the link to a difference between traditions of Islam in Russia and the Polish-Lithuanian state, the Polish-Lithuanian Tatars received consent to election of imams, therefore, priests from outside were not sent there. For example, priests from the Crimea or Kazan badly got on with a new community and knew only Russian. They were easily allowed to build mosques. It, however, didn't mean that there was no recurrence, discrimination. In 1874, for example, the imperial government under the guise of release of Muslim Spiritual Directorate from duties to dispose of waqf lands, took away from them grounds at mosques (for weakening of a position of Islam). According to representatives of the Russian administration, the Tatar waqfs were harmful and undesirable phenomenon.

Discrimination against the Muslim population was also manifested in the fact that the pilgrimage to Mecca and Medina became practically impossible. Although the Russian government law did not prohibit travel to the holy places, however officials often did not issue passports.

However, to be objective, the situation of the Polish Tatars in the end of the XIX century was significantly better than of the other Muslim peoples of the Russian Empire.

The favorable religious situation was in many respects, due to good attitude of administration to the Polish Tatars. They felt in relative safety, because of having the generals and colonels in the Russian army. Some of them were even patrons of the major mosques. For example, at the end of the XIX century the general Matsey Tugan-Baranovsky became the patron of a vilensky mosque.

\section{Discussions}

The problem considered in article is poorly studied in a national historiography. Except for several early publications (in the 60th of the XIX century) of professor and the dean of Faculty of Oriental Languages of the Petersburg University Anton Mukhlinsky, there were some superficial newspaper articles, neither in Russia, nor in the USSR wasn't serious research on this issue. The destiny of the Polish-Lithuanian Tatars as the real and instructive historical phenomenon is noteworthy. The author of this article, investigating extremely interesting aspect from history of the Polish-Lithuanian Tatars - their religious life, seeks to promote elimination of white spots of a national historiography in this peculiar area of Turkic studies.

\section{Conclusion}

In general, the Lithuanian Tatars were deeply faithful to the religion and even if they weren't engaged in proselytism, so peculiar to Muslims, because of political weakness, they strictly observed their brothers in faith not to change the law of Mahomet, if there was something similar, didn't stop before blasphemy, even before violence in relation to the persons which accepted Christianity". And, as mentioned in Akti, this explains the fact that getting much Polonised, Lithuanian Tatars to our times (beginning of the XX century. - Y. Grishin) kept their religion.

In the Polish-Lithuanian state only Tatars were supporters of Islam in its devout form (Sunnites). As a relatively considerable group, keeping contacts with sworn brothers from the Crimea and the Volga region, they organized the religious life on constant legal bases and customs. It is possible to say safely that the Lithuanian-Polish Tatars kept the cultural and ethnic difference through many centuries, mainly, thanks to cultivation of Islam. The religious factor united them in the gmina, allowed to keep distinctive ceremonies, allowed to get married in own circle of believers (Tyszkiewicz, 1989).

\section{Acknowledgments}

The work is performed according to the Russian Government Program of Competitive Growth of Kazan Federal University

\section{References}

Akti o litovskih tatarah. (1906). Vilno. T.XXXI. C.XXV, XXVI, XXVII: 90, 179, 180, 186, 190, 195, 203, 288, $290,485$.

Bohdanowicz, L., Chazbiewicz, S., \& Tyszkiewicz, J. (1997). TatarzymusulmaniewPolsce. Gdaǹsk, 17, 40, 66-70.

Borawski, P. (1986). Tatarzy w dawnejRzeszcrpospolitej. Warszawa. 
Borawski, P., \& Dubiǹski, A. (1986). Tatarzypolscy.Dzieje, obrzędy, legendy, tradycje. Warszawa.

Chazbiewicz, S. (1994). KulturareligijnaTatarówpolskich. RocznikTatarówpolskich.T.II. Gdaǹsk, 83.

Grishin,Y. (1997). 600 let sovmestnoi zhizni. Kratkaya istoricheskaya khronika. XIV - XX v.v. Kazan, 1-51.

Khayrutdinov, R. R. (2014). Museum Conference of 1926 in Kazan. World Applied Sciences Journal, 31(2), 193-195.

Kirkor, A. (1854). Velikiy knyaz Vitovt. Cherti iz istorii zhizni litovskogo naroda. Vilno.

Kołodziejczyk, A. (1986). Przyczynek do historiiTatarówbialskich. Archeion. XXX, 224, 228.

Konopacki. (1973). Tatarszczyznunąpolskąmodlą. Znak, 2, 15-64.

Kryczyǹski, L. (1930). Rejestrdokumentówna dobra tatarskieLostaje (1600-1789). Ateneum Wileǹski. VII, $1-2,13$.

Kryczyǹski, S. (1938). Tatarzylitewscy. Próbamonografiihistorycrno-etnograficznej. Roczniktatarski. T.III. Warszawa: 25,186-187, 204-207, 212.

Muchliǹski, A. (1858). Zdanesprawy o Tatarachlitewskich. Teka Wilenska, 4, 258.

Mukhlinskiy, A. (1887). Issledovanie o proishozhdenii i sostoyanii litovskih tatar. Sankt-Peterburg, 50.

Piechnik, L. (1973). Początki Akademii Wileǹskiej. Nasza Przeszłość, 40, 13.

Tyszkiewicz, J. (1989). TatarzynaLitwieiwPolsce. Warszawa, 281-282, 292, 293, 299.

Woronowicz, A. (1937). Przyczynek do historiimeczetów w Polsce. Życietatarskie. R.IV, 12, 1-6.

Zakrzewski, A. (1937). Osadnictwotatarskiew Wielkim Księstwie Litewskimaspektywyznaniowe. ActaBaltiko, 140-141, 143-144, 145.

Źdan, M. (1929). Stosnukilitewsko-tatarskiezaczasów Witolda, Wielkiego Księcia Litwy. Ateneum Wileǹskie. R.6, $562,572$.

\section{Copyrights}

Copyright for this article is retained by the author(s), with first publication rights granted to the journal.

This is an open-access article distributed under the terms and conditions of the Creative Commons Attribution license (http://creativecommons.org/licenses/by/3.0/). 